ARXIU D'ETNOGRAFIA DE CATALUNYA, N. 3, 1984

\title{
AIXÍ DANSEN ELS ESPERITS
}

Salvador Anton Clavé i Xavier Virgili Abelló

Institut Tarrạgonès d'Antropologia 
«Un reportatge? Una obra d'investigació cientifica? ¿Una interpretació antropològica?. Són aquestes tres coses, com a mínim, les que reuneix el llibre La dansa als esperits, del professor Lluís Mallart. El lector, doncs, podrà experimentar la diversitat de sensacions que produeix la lectura d'una narració fascinant, l'interès de la recerca científica i la curiositat d'unes conclusions suggeridores.»

Així comença el full de promoció de La Dansa als esperits. D'aquesta manera és com es dóna a conèixer al públic un llibre que, en paraules de l'autor, «... no vol ser més que una contribució en català a l'antropologia religiosa africana” (MALlart, 20). I no és banal aquesta acotació. És més, gosariem a dir que Mallart la té ben present a l'hora de redactar l'obra. I diem l'obra perquè no volem caure en la temptació de dir «el reportatge» o «la investigación o «la interpretación; perquè, com ben bé recull la ressenya editorial, la principal qüestió entorn d'aquest treball és la seva definició, o la seva classificació, si voleu. Certament, tothom hi pot dir la seva. Certament admet més d'una lectura. Certament fascina, colpeix i suggereix. Certament aquesta és la seva virtud...; o el seu defecte. De totes maneres, el que pensem que sí que cal fer notar és que el caràcter primerenc -en l'aspecte lingüístic ja comentat - d'aquesta obra pot haver determinat en algun sentit el seu contingut, és a dir, pot haver estat plantejat en bona mesura com una obra de divulgació en sacrifici d'aspectes, anàlisis i plantejaments més científics però potser menys interessants al gran públic, per al qual el llibre pot ésser perfectament un llibre d'entreteniment. Aquest no és el nostre cas, i per això en els pròxims fulls intentarem donar una visió més exhaustiva de tot allo que ens ha suggerit La Dansa als esperits.

Però deixem-nos de possibles valoracions «comercials» -i sigui dit de passada que l'obra es llegeix agradablement $i$ interessant; que hom «es fa amic del protagonista, en Mba Owona, com se'n faria d'un personatge de novella; o que la fluidesa del llenguatge és primmirada- $i$ endinsem-nos en dos aspectes fonamentals per a poder seguir parlant d'ella: què diuen les 270 planes del volum i com ho diuen, tot des d'una perspectiva el més assèptica possible: 
Mallart presenta un cas d'iniciació xamànica entre els Evuzok del Camerun, a partir de la qual vol bastir un model teòric de tipus estructuralista que contribuieixi a l'estudi de les dues formes úniques de comunicació entre «el món visible i l'invisible, entre els homes i els déus, esperits o altres éssers supranaturals" — si emprem les seves pròpies paraules (MALLART, 9-10)—, és a dir, la possessió i el xamanisme. Això pretén fer La Dansa als esperits.

No apuntarem ara $\mathrm{i}$ aquí el seguit de passos que Mallart recull, ordena i exposa $\mathrm{i}$ que basteixen detalladament l'exemple. Ens estalviem d'assenyalar les vicissituds que va patir aquest noi camerunès pel fet de ser triat pels esperits, de ser iniciat per ells $\mathrm{i}$ d'esdevenir medecinaire. Deixem també a la lectura dels interessats la descripcí́ de la «Dansa als Esperits» o dels relats de curació que empra Mallart per a especificar uns certs tipus d'ús del ritual. Tot $i$ saber el risc «informatiun que això pot comportar, $i$ perquè no volem fer un resum sinó esperonar al diàleg, creiem que seran prou illustratives les pròpies paraules de l'estudiós:

aLa Dansa als Esperits - tema central d'aquest llibre- és el nom de l'acte ritual celebrat per aquest medecinaire, en el transcurs del qual uns ésser supranaturals fan irrupció (moviment descendent) al bell mig d'un espai humà, entren en contacte físic amb el medecinaire i l'arrabassen (moviment ascendent) per empendre plegats un viatge envers l'univers medicinal on tenen llur habitacle. Però aquesta Dansa, no és res més que l'expressió ritual d'una llarga història sobre l'elecció pels Esperits i la iniciació d'aquest medecinaire, la comprensió de la qual ens permetrà de copsar millor el sentit d'aquell acte ritual. Es així com a les planes d'aquest llibre un mite d'iniciació $\mathrm{i}$ un ritu de curació s'illuminaran l'un a l'altre com la paraula iHumina l'acte que engendra, $\mathrm{i}$ viceversa.» (Mallart, 1983: 10).

No cal llegir gaire atentament aquest fragment per a treure'n un parell de trets que seran determinants en el segon dels aspectes dels que, de moment, ens havíem proposat de parlar. «La dansa, diu Mallart, és l'expressió ritual d'una llarga història.» Aquesta distinció, història-dansa que més tard comentarà amb expressionś com ara: «El discurs iniciàtic té tot el caire d'un mite fundador, però amb una diferència important (...), intenta explicar l'origen fora del temps d'un fet o d'una institució social». (MallarT, 107) o d'altres on s'estableix un paraHlelisme entre els moviments ascendents i descendents que s'articulen en un $i$ altre fenomen (vid. MALLART, 118) estarà cendents que s'articulen en un i volum i d'una manera molt clara. En el llibre distingim aquests dos fenòmens gràcies a la mateixa distribució per capítols. Distribució que sembla rigorosament establerta i que reflecteix for- malment el contingut de les seves paraules i, això és ja més significatiu, l'ordenació i la interpretació que Mallart fa d'un material que $a$ priori suposem que debia aparèixer amorfament. Sobre això hi tornarem. D'altra banda en aquell mateix fragment se'ns invita a comprendre el sentit de l'acte ritual a través de la lectura d'un $\mathrm{i}$ altre fenomen. Apuntem des d'ara que interroguem l'investigador sobre la manera com fer-ho. Les raons ja les exposarem per tota la ressenya.

En aquest mateix context de com diu Mallart el que diu cal que introduïm un segon element fora de la cita. Així doncs, cal dir que Mallart juga amb dues parts de contingut. I ho fa a dos nivells. Per una part, constantment barreja les paraules del medecinaire amb elaboracions teòriques pròpies - comparacions, conclusions, interpretacions, etc.-. Per Paltra, i a nivell més global - d'estructura de l'obra-, alterna capitols de caire pràctic amb capítols de caire teòric: 1-2: elecció $i$ iniciació de Mba (pràctic); 3: estructura i funció dels relats iniciàtics (teòric); 4-5: la Dansa als esperits $i$ els relats de curació (pràctic); epíleg i primer annex (teòric). Això com a mínim reporta una fluidesa $\mathrm{i}$ amenitat a l'hora de llegir el llibre que lliga molt bé amb aquella apreciació que feiem poc abans referint-nos al possible receptor de l'obra. D'aquesta manera, Mallart intercala document viu amb interpretació antropològica. I això ho fa tant dintre de cada capítol com en un capítol específic enmig de la història i de la dansa, en parlar de l'estructura i funció dels relats iniciàtics. La validesa d'aquestes interpolacions interpretatives, tant si considerem el conjunt de l'obra com la seva eficàcia són més que discutibles. També hi tornarem.

Cal dir encara que La Dansa als esperits és presentada amb dos annexos, l'un, el darrer, és la transcripció en la llengua indígena dels cants que Mallart ha traduit al català en incloure'ls en l'obra, i l'altre que és el text d'una conferència donada per ell mateix, summament explicativa i que cobreix algunes de les mancances de les quals el text nu sens dubte s'hauria ressentit. Aquest annex juga un paper altament significatiu, ja que explica ordenadament $i$ polida la connexió entre religió $i$ medicina en la mateixa societat africana on Mba fa la seva Dansa, la del poble Evuzok.

A partir de tot el que hem vist fins ara, pensem que el que cal plantejarse és com treballa Mallart, quina és la tècnica per a ell més adequada i alhora la que ha seguit per a realitzar el llibre que ara analitzem. La seva concepció de què ha d'ésser l'etnografia és força clara:

* Jo crec que l'etnografia ha d'ésser el resultat d'una relació humana sincera, plena de respecte envers l'altre. Aquesta relació, a més, ha de crearse tenint en compte les formes de comunicació social usuals en la societat en la qual l'antropòleg viu.» (Mallart, 1983: 19). 


\section{D'aquí a la tècnica, un pas:}

«En una societat allunyada - gràcies a Déu! - de les modernes tècniques del marketing, la utilització d'un qüestionari és el mètode menys adequat

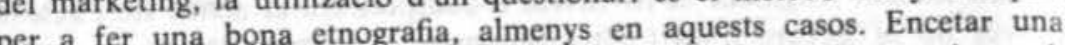
conversa, mantenir un to ben informal, deixar parlar i saber escoltar, ad. metre la possibilitat d'una disgressió o del fil que es trenca per un acudit. acceptar la frase buida o el silenci que tradueix el dret legítim d'una certa reserva, $\mathrm{cm}$ sembla que és la millor manera per a crear el clima d'espontaneitat que ha d'animar la recerca etnogràfica.» (Mallart. 1983: 19.)

I és així com ho fa. La Dansa als esperits és bàsicament una entrevista, realitzada molt possiblement amb tots els trets que Mallart acaba d'assenyalar. A partir d'ella, Mallart inclou valoracions pròpies. Tanmateix, pensem lar. A partir d'ella, Mallart seriosament la utilització d'aquesta tècnica de treball com a exclusiva per a realitzar un estudi. No manquen exemples de monografies antropològiques que fan de l'entrevista l'única arma de treball, però cal tenir en compte en quines circumstàncies ho fan. Fer una història de vida utilitzant com a únic instrument les paraules del protagonista no ens porta més enllà que a satisfer la curiositat del lector de saber com ha viscut una persona determinada. Això és força factible quan l'estudi es realitza sobre una persona del nostre $\longrightarrow$ semblant - món cultural. Aleshores no cal iniciar un discurs sobre l'economia, les creences, el parentiu, l'estructuració social, etc., del poble al qual pertany la persona estudiada. Però aquest no és contrari. El relat de Mba és es portes a tots aquests aspectes. Però no és simple curiositat per saber-ho. Més aviat és necessitat. No serveix de res dir que

Tots els infants se n'anirien a viure a casa dels germans de la mare. En cap més lloc no estarien més segurs." (Mallart, 1983: 26).

sense realitzar una anàlisi del parentiu que ens faci entendre aquestes parausense realitzar una analisi del parentiu que expliquin les mi les i moltes d'altres de semblants. Poca cosa és que se'ns expliquin les mi i una curacions de Mba Owona si no se'ns diu quin valor social reconegu tenen els medecinaires avui en dia al Camerun, si aquest valor és tan eleva al món rural com a l'urbà, quines possibles interferències administratives es donen al desenvolupament de l'ofici de medecinaire, quina pos ible relació colonial del país, quina és aquesta sible relació té aixó amb lestructura colonial del pais, quina es aquesta prou. I Mallart s'hi ha quedat. O almenys a La Dansa als esperits així ho fa. L'entrevista, fil conductor de l'obra, va vessant noves possibilitats i obrint nous camins a través del seu desenvolupament $i$ això no està aprofitat. I com hem dit, no és que Mallart es limiti a posar les paraules de Mba. Fa una elaboració pròpia, però a un altre nivell que està també necessàriament esbiaixat. Així doncs, Mallart ens transmet un document, i una manipulació. El document, és el relat i els comentaris que de la seva dansa fa en Mba, un jove que s'ofereix voluntàriament a Mallart per explicar-li què fa i que provoca en l'antropòleg una primera reacció de recel. Mallart ho explica honestament $\mathrm{i}$ fins $\mathrm{i}$ tot ho emprarà com a un element més per explicar la transformació que pateixen les societats indígenes africanes sota una forma de dominació colonial o neocolonial. Mallart entrevista Mba i d'això en surt una història de vida que configurarà la primera part del llibre, és a dir, la història de l'elecció i la iniciació de Mba. Referides a aquest punt recuperem dues idees: l'una posa en dubte - com ja hem dit- la validesa de sustentar només sobre la història de vida d'un personatge representatiu, en el sentit de ser-li reconegut un prestigi en la seva pròpia societat, un seguit de conclusions $\mathrm{i}$ consideracions de caire divers $\mathrm{i}$ que impliquen la cosmologia de tota una societat donant-la per certa. S'ha discutit sovint si una narració biogràfica que explica una pràctica humana expressa el sistema social sencer en la seva dimensió estàtica i dinàmica, si és un reflex social o bé el mediatitza, si el filtra o el tradueix. D'acord. Creiem tanmateix que no ha de ser possible jugar amb el mateix tipus de consideracions quan la pràctica humana és quotidiana o vulgar (en el sentit de corrent) que quan la pràctica humana en qüestió és extraordinària, com és el cas que ara ens ocupa. El tema resta en l'aire, ja que no pretenem discutir-lo ara. En el cas que admetessim la validesa de la història de vida en aquesta circumstància hauríem de considerar la tècnica de l'entrevista. En el cas que ressenyem ja hem dit que l'entrevista és el fil conductor de l'obra, és més, és l'únic fil conductor. A redós seu apareixen tota una sèrie d'elements que no són ni gairebé esbossats (parentiu, societat, economia) i que minven la capacitat entenedora del lector. Vist això, preguntem de nou: és possible només l'entrevista? No són necessàries altres tècniques per tal de tractar aspectes recurrents que apareixen en les paraules del medecinaire? Quin sentit té obrir portes al lector si no se li deixa passar el llindar? Hom pot objectar que aquest no és el propòsit del volum, sinó només explicar la «Dansa als esperits»; però és que sense aquests recursos la recuperació de la Dansa esdevé folklòrica. No s'hi val a descontextualitzar-la o a referir-la només a aspectes cosmològics del

món Evuzok (o de Mba caldria dir?). S'ha de veure com s'inserta en una xarxa social i econòmica que creiem molt trasbalsada. Això ho veurem més 
detingudament en parlar de les interpretacions. En un altre sentit, hem de lloar l'excepcional coneixement de la llengua evuzok per part de Mallart. Mba coneix el francès - llengua en la qual per causa d'un alumne que acompanyava Mallart es realitzaren les converses- però Mallart coneix l'ewondo, llengua dels evuzok —en la que realitzà les preguntes fetes a Mba-, i la coneix cal dir que molt bé. Un exemple:

«Diguem de passada que la terminologia utilitzada en aquest paràraf coincideix amb la utilitzada per l'autor del relat quan diu que l'ànima del pare de Joana Nogono va "arrabassar" la seva filla per a donar-la als Esperits. Mba Owona no utilitza mai el verb "elegir". En el seu lloc empra el verb francès prendre, que no és sinó una feble traducció del verb ewondo bi, que s'usa en aquests casos, i que té un sentit molt més fort.» (Mallart, 1983: 60-61).

Arribar a poder dir això és filar molt prim i possibilita un coneixement d'allo que s'estudia molt profund. D'altra banda ens preocupa assenyalar el tipus de traducció que Mallart - $\mathrm{i}$ possiblement els seus coHlaboradors i amics que l'engrescaren a fer aquest llibre en català- fa de les paraules de Mba. D'elles a la literatura, molt poc. Mallart entra en contradicció - pensem que molt destacable $\mathrm{i}$ important- amb el que ell mateix afirma $\mathrm{i}$ que ja hem citat anteriorment. A les traduccions de les paraules del medecinaire no es nota el to informal de la conversa - millor dit, no s'hi veu conversa sinó més aviat monòleg-, ni les disgressions de l'entrevistat ni molt menys els fils trencats per acudits, les frases buides o els silencis significatius que Mallart creu tan importants. Quan hom llegeix les paraules de Mba, té més la impressió d'estar davant d'un erudit que deixa anar al vent els seus pensaments madurats que no d'un medecinaire evuzok que està explicant la seva experiència vital a un antropòleg europeu. Les transcripcions que fa de les paraules de Mba són vertaders fragments literaris, com ja hem dit. Hom pot suposar que, salvant la traducció, Mba parlés tan bellament, però sempre tindrem també el dubte que no fos així. En aquest cas apostem, proclamant fidelitat, per l'expressió barroera.

L'elaboració, dones, del discurs de Mba és evident. Però ja no tan sols al nivell que acabem de dir, sinó encara en un altre potser - només potsermés important. De mostra un botó; això es diu a la ressenya que del mateix llibre apareix al final de l'obra: «En aquest llibre, ens lliura - referint-se a Mallart- una part de les converses que hi va mantenir...». Es a dir, no tot el que digué Mba de la seva experiència es troba recollit a l'obra. Això presuposa una elaboració, una estructuració nova del material un cop eliminat una part del mateix. En definitiva, el relat que podem llegir al llibre en boca de Mba no recull ni les paraules que ell digué, ni l'ordre en que les digué ni la totalitat de les mateixes. El producte que podem veure a les planes de La Dansa als esperits no és el simple fruit d'una xerrada, sinó d'un treball a priori i posteriori molt important. I això no se'ns diu ni s'especifica de cap de les maneres, donant la impressió contrària, que el que apareix en boca de Mba, és tot el que ha dit, l'ordre en que ho ha dit i les paraules exactes que ha emprat.

Abans de passar a considerar el que més amunt hem anomenat manipulació (entenent amb aquesta paraula l'ús que Mallart fa del document per tal de contribuir a l'estudi de les dues formes de comunicació supranatural esmentades; és que s'inclou en un determinat corrent antropològic), considerem que hem d'abordar alguns aspectes relacionats amb les interpolacions interpretatives de l'autor i amb els mancaments contextuals. que en algun altre lloc ja hem assenyalat $\mathrm{i}$ com s'entenen en el propòsit de l'autor. Tenint present que «... el relat de Mba Owona només serà comprès per nosaltres si el considerem en relació amb la Dansa als Esperits i acceptat pels Evuzok si n'experimenten el seu caràcter benèfic» (Mallart, 1983: 103:104), hem d'entendre les paraules que tot seguit transcriurem referides al discurs iniciàtic en una doble vessant; és a dir, com a exègesi de la dansa. El fragment diu:

«...el discurs iniciàtic no és autònom, sinó que s'inscriu en el marc més general d'un discurs religiós els límits del qual són ben coneguts. Així doncs el seu contingut ha de conformar-se, almenys en els seus elements essencials, amb el contingut propi d'aquell model religiós elaborat per la societat a la qual pertanyen l'autor del relat iniciàtic $i$ el seu auditori.» (Mallart, 1983: 105).

Tant el discurs iniciàtic com la dansa s'han transformat. Si tots dos fenòmens s'han d'adequar a la societat que els ha d'acollir, s'ha d'entendre que la transformació s'ha produit a redós d'un canvi social i econòmic. Sense entrar en el tema de la colonització o de l'explotació que actualment pateixen moltes societats indigenes arreu dels països subdesenvolupats, sí que volem assenyalar com Mallart interpreta les innovacions que Mba inclou en la seva dansa:

*I és a través d'aquestes innovacions com un poble expressa la seva oposició reiterada a totes les temptatives que conduiran una societat que preconitza una certa igualtat entre els seus membres, a una altra forma d'existència social basada en la desigualtat, l'individualisme, la concentració de poder i l'acumulació no compartida dels seus béns.» (Mallart, 1983: 231). 
En principi acceptem la tesi que la «nova Dansa» és una resposta espiritual a la dominació colonial. De fet és significatiu que la Dansa, tal com la interpreta Mallart, inclogui representacions socials i econòmiques foranes i que precisament s'hi ubiquin en el domini contra el qual el medecinaire ha de lluitar, aquesta constatació està específicament illustrada amb la bruixeria anomenada del kong:

«Per comprendre la manera de concebre aquesta nova forma de bruixeria convé tenir present dos fets històrics: el comerç d'esclaus i la introducció durant l'època colonial d'una economia basada en l'explotació de plantacions de cacau i de cafè. (...) El tema de l'antropofagia o de la devoració, és substituit així pels temes de l'esclavatge i de l'explotació. (...) En tots dos casos, però, és indubtable que aquest sistema de bruixeria no pot explicar-se sense referir-se a la presència dels blancs $i$ del poder colonial en aquestes contrades. Es per això que els Evuzok afirmen que aquesta nova forma de bruixeria no és nadiva; que són els blancs els qui van introduir-la al Camerun $\mathrm{i}$ en coneixen millor els secrets.» (Mallart, 1983: 213).

Tanmateix, el nostre interès és de ressaltar que la documentació que Mallart explicita per a sustentar que la tesi més amunt assenyalada és ben minsa. Gairebé no sabem ni amb què s'articula la «nova» dansa. ¿Quina és aquella societat la qual té un model religiós capaç d'acceptar-la i per què? De fets tots els mancaments contextuals són ingents. Pot ser que sigui qüestió d'escolta, però... En aquest sentit, les preguntes sense resposta que suggereixen els comentaris de Mallart són nombrosíssimes: si la transformació de la dansa és evident, ¿quins trets, mai que sigui els més significatius, té aquesta societat «en canvi» que l'accepta? Per què la modificació? ¿Quina intenció lucrativa hi pot haver darrera? O si no lucrativa sí de subsistència? ¿Com s'entèn que la nova dansa rebutji idealment la societat colonial, però en la seva realització inclogui uns prejudicis i privilegis adoptats d'aquella? I Mallart què en diu?

Mallart simplement presenta un ritus que no articula en una societat concreta. L'interessa més la Dansa com a element illustrador de «lluita de concepcions» que no pas el valor intrinsec de la Dansa en la societat on s'ha generat. Això es veu clar en aquest llarg fragment:

«Es interessant constatar que aquesta forma de representar-se l'organització de la comunitat dels Esperits es troben reunides i ben diferenciades (governar, defensar-se i produir) que G. Dumézil ha demostrat que són presents en tota la mitologia indo-europea. Sense voler establir una relació de causa a efecte, el pas donat per Mba Owona i a través d'ell la societat que acull el seu discurs, semblaria correspondre a les transformacions que en aquests darrers temps s'han operat en totes les societats lògiques de la malaltia tambés endavant les noves interpretacions etiologiques de la malaltia també tenen en compte aquestes transformacions, caire tribal (...) les difere econòmic i social. En una societat tradicional de doncs, i considerant de nou el cas no són massa pronunciades (...) Així, la seva concepció tradice nou el cas dels Evuzok, no és gens estrany que en la seva concepció tradicional del món dels Esperits, les funcions que els moment en què ho areguessin tan elaborades com ho són avui, en un tificació social la societat veu néixer en el seu si una nova forma d'estratificació social o, si més no, en què les seves estructures tradicionals es (...).» (Mallart, 1983: 33-34).

Però quina és la societat tradicional i la colonial? Fins on arriba l'una i l'altra? Com s'entén aquesta afirmació que tot seguit transcrivim:

"La ciutat, amb tot allò que suposa de ruptura amb el món tradicional, semblava presentar-se-li com una mena de refugi per a alliberar-se d'aquest tipus de manifestacions sobrenaturals. La seva anada a Yaundé i els seus estudis deixen entreveure en tot cas el seu proposit de prepararse per a fer una carrera al marge de la vida tradicional.» (Mallart,
1983: 47).

o aquest comentari del propi Mba:

«Posem per exemple el cas de Zogo Jean, que estic tractant actualment. El seu cas és senzill, car aquest individu no sap res (del que li han fet). El tant, no gena, car tenia por que el seguint els procediments de la medicina indiI'Hospital prenia por que el Pastor s'enfadés. (...) Primerament va anar a anar a veure Nktant de Bibia sense obtenir cap millora. Després se'n va no coneix els nous tractament, però com que aquest medicinaire ja és vell xeria (...).» (Mallart, 1983: 208.) avui existeixen noves formes de brui-

En definitiva, ¿quin és el trasbals vertader d'aquesta societat $i$ per què, si és així, la Dansa als Esperits hi cap dins? Què vol indicar-nos Mallart en
parlar del deixeble de Mba:

«Amugu és un jove evuzok d'una vintena d'anys que es prepara per a esdevenir medicinaire sota el mestratge de Mba Owona. (...) En altre temps havia conegut el seu avi, avui ja mort: un vell venerable que havia 
coHaborat amb els primers missioners alemanys per a fundar la missió catòlica d'aquesta contrada. Per quines raons el seu nét roman al país natal i segueix una iniciació de caire tradicional quan gairebé tots els joves de la seva generació estudien o treballen als centres urbans? No ha sé pas. Es interessant constatar, però, que en un moment de profunđa transformació de la societat, un xicot jove com Amugu, fill d'una família evoluée, és a dir, integrada en la vida moderna, es prepara per a esdevenir medecinaire. Un retorn a la tradició? Es massa aviat per a reafirmarho, però els casos de Mba Owona i Amugu semblen indicar-ho...) (Mallart, 1983: 145).

I si és així, a quina tradició retorna? A la que encara persisteix a nivell cognitiu quan es fa esment de la relació entre Mba i el seu Esperit principal (que cura) i que es reflexa en aquestes paraules:

«El diàleg entre Mba Owona i Adela sembla evocar l'ambigüitat d'aquestas relacions. (...) Així, doncs, i com en el cas de les relacions entre Pigmeus i Bantús, cada un conservarà una veritable autonomia dins els límits d'una dependència recíproca. Les referències al món dels Pigmeus, presents en tot aquest relat, em fa pensar que en definitiva el sistema de relacions entre el medicinaire i els Esperits no és sinó la transposició a nivell simbòlic del sistema de relacions que existeix entre el poble Evuzok $i$ les bandes de Pigmeus que viuen en aquestes contrades." (Mallart. 1983: 92.)

O és que la dansa actua d'explicació lògica de l'illògic com semblen apuntar aquestes cites, l'una paraules de l'antropòleg, l'altra, de Mba:

«No sóc jo el qui cura la gent, proclama sense cap ambiguitat Mba Owona, sinó els meus Esperits. (...) En un moment de crisi i de transformacions socials profundes, enmig de les quals les creences en la bruixeria s'afermen $\mathrm{i}$ es desenvolupen, la Dansa als Esperits fa la seva aparició aportant una nova certitud: l'eficàcia del ritual depèn essencialment dels Esperits.» (Mallart, 1983: 169).

«Quan a una persona li van bé les coses, els bruixots es reuneixen diuen entre ells: - "Això no pot ser...! Mireu en tal quina família més nombrosa que té...! Totes les dones del seu llinatge li pareixen...! A més a més, mireu quines plantacions de cacau més grans que té.... A aquest home hem de matar-lo...!" - I tot seguit busquen la manera de fer-ho..." (Mallart, 1983: 184).

Com hem dit, Mba Owona havia estat un xicot urbà que en un momen determinat decideix retornar a les seves arrels i exercir una tasca d'alguna manera «especial» dins la seva societat. Com hem vist també, Mallart es qüestiona - i sembla subscriure-ho finalment - el retorn a la tradició. Com a molts d'altres punts interessants, no hi aprofondeix $\mathrm{i}$ ho deix en l'aire, com si no tingués més importància, quan en realitat obre un camí molt interessant, malgrat tenir-ne material per a fer-ho. Sino, observem què li diu Joana Ngono, la iniciadora de Mba, en un moment determinant:

«Si vols que et lliuri tot el que jo sé, m'hauràs de donar tres-cents mil francs.” (Mallart, 1983: 75).

Simple economia? Simple llei de l'oferta i la demanda? Això és tradició? A través de les paraules de Mba es recull que cobra les curacions que un cop iniciat porta a terme i cal suposar que també fa pagar la iniciació als seus «alumnes». Amb tot això volem qüestionar la mena d'idealització que sembla surar en el relat i que faria de Mba gairebé un illưminat que en un moment determinat sent la necessitat de servir al seu poble. A partir d'aquí podem començar a parlar de la participació en un doble món, el món de la ciutat $\mathrm{i}$ el del poble. És impossible i seria altament ingenu pensar en aquests dos nuclis, sectors, àmbits o com vulguem anomenar-los, aillats un de l'altre, purs i sense cap relació. Com després analitzarem, el sector urbà és un sector artificial, superposat a un territori amb estructuració pròpia per un poder colonial del segle passat. Però del que ara es trata és de preguntar-nos entre ciutat i poble quin tipus de relació poden establir-se, és a dir, fins a quin punt l'habitant d'un poblat rural és alhora un obrer, amb quina freqüència els habitants rurals es veuen necessitats d'anar a la ciutat ja sigui per comprar, realitzar tasques administratives o visitar un familiar; com arriba, circula $i$ se'n van els diners entre la gent d'hàbitat rural; a quins sectors de l'estructura familiar tradicional ha afectat l'emigració cap a la ciutat -i el caràcter pendular o definitiu d'aquesta emigració-; el grau d'urbanització - per imitació o d'altres causes- que pateixen els pobles; la visió que els habitants rurals tenen del món urbà i vice-versa. En definitiva averiguar la quantitat important de fluxes establerts reciprocament entre ciutat i camp, la llunyania dels quals - $\mathrm{i}$ no en quilòmetres precisament- no podem establir en llegir La Dansa als esperits. Tornant a la tradició, pensem que per afirmar que la tornada de Mba de la ciutat al camp i el fet de fer-se medicinaire són un retorn a ella, és a dir, a la vida que secularment ha portat el poble Evuzok, hem de presuposar abans dues coses. La primera que el poble Evuzok ha viscut sempre de la mateixa manera, «de la manera tradicional», i la segona que aquest mateix poble ha decidit en un moment donat de recuperar aquella manera de vida, puix que el que pensem seria ingenu dir és que 
aquest reюrn a la tradició s'hauria produït només en un home, Mba, que hauria de portar a terme una tasca educacional per tal de fer veure al seu poble la necessitat de viure com «abans». Un poble, amb tots els seus trets, es troba sempre en constant canvi, i d'això se n'adonen els seus integrants generació a generació malgrat que potser a un observador forani li pugui semblar que sempre han viscut de determinada manera. El canvi produït per l'estructuració colonial és un d'ells. Molt més fort, molt més dràstic, imposat per unes potències estrangeres, però alhora un canvi més. Ha estat força negatiu - cosa que després analitzarem- mirat d'una manera objectiva i per nosaltres, però quina visió en poden tenir aquestes gents? Fins a quin punt el sistema no s'ha menjat la seva objectivitat $i$ arriba a semblar-els-hi positiva una manera de vida que en el fons els perjudica? Amb tot això volem destacar que no queda pas clar ni què hem d'entendre pel concepte de tradició $\mathrm{i}$ que en tot cas el retorn a ella no podria quallar tan fàcilment en un poble «canviat" per la mateixa causa —el món colonial- del que ara voldrien fugir. El procés aculturatiu és, doncs, força evident i ningú no el pot negar.

El món colonial ha canviat tot allò damunt el qual s'ha establert. Però d'una banda no coneixem la societat Evuzok - només sabem que era una societat igualitària que ara tendeix a no ser-ho per la influència colonial que esmentem-; no sabem pràcticament res del seu parentiu, de la seva economia, de les seves relacions amb els pobles veïns, de la manera d'organització política, dels costums, de les festes, de les relacions intergeneracionals, de la concepció de propietat, etc. No sabem res de tot això, si es manté respecte a com estava abans de la vinguda dels estrangers, si ha canviat - segur que sí- i en la mesura amb que ho ha fet. L'aculturació ha estat evident, però no en sabem el grau concret, la data illustrativa que ens pugui fer cinc cèntims, ni - com deiem abans- l'acceptació que aquesta aculturació ha tingut entre els indígenes. El que a partir d'aquí volíem introduir és la possible funció desintoxicadora del ritual de Mba, però una desintoxicació que rebutjaria aquella portada a terme pels estrangers. Veiem la cita:

"Així es passa de la concepció d'una societat fundada en els lligams que crea el parentiu (la societat real), a una altra fundada únicament en la reeixida personal (la societat dels bruixots). /.../ La bruixeria pot ser considerada com una forma d'ideologia que aquelles societats estructurades a base de llinatges $i$ sense un poder polític centralitzat es donen a si mateixes per tal de lluitar contra aquelles desviacions que podrien con duir-les a una altra forma de societat menys horitzontal, en la qual els lligams fundats en el parentiu tendirien a desaparèixer per a donar pas a una estructura jeràrquica fundada en l'individualisme, la reeixida perso- nal i la concentració de poder a les mans dels més forts.» (Mallart, 1983: 186-187).

Aquesta és precisament la tesi que sosté en Mallart. La dansa, el ritual, Mba i la seva medecina lluitant contra el món dels estrangers. Encara més clar:

«La desestructuració de la societat provocada pel procés de colonització i d'occidentalització ha tingut com a consequèència l'increment d'aquelles creences relacionades amb la bruixeria. Fonamentalment, la bruixeria evuzok és una interpretació a nivell simbòlic de tot el que pot aparèixer com contrari a l'ordre establert pels avanpassats. Els canvis introduits pel procés d'occidentalització són sovint interpretats com una temptativa de desestabilització d'aquest ordre. La recrudescència de les creences en la bruixeria ha estat, doncs, una conseqüència normal articulada amb la lògica pròpia del sistema tradicional. D'altra banda, la colonització -ajudada en això per l'acció de les Esglésies missioneres- va desorganitzar d'una manera particular aquell àmbit relacionat amb l'ordre (social) instaurat pels avanpassats. /.../ Amb això no tan sols es va aconseguir desorganitzar la societat, sinó que se la va despullar d'un dels mitjans més importants (el culte als avanpassats) per a lluitar contra la bruixeria, la qual cosa no podia sinó ser interpretada com un gran triomf d'aquesta última.n (Mallart, 1983: 230-231). altres:

I aquestes paraules queden ja plenament arrodonides amb aquestes

Mba Owona és més que un medecinaire. Es el darrer testimoni del refús d'una societat tribal de caire "democràtic" a veure's convertida en una societat d'inspiració "autocràtica",» (Mallart, 1983: 230).

Mallart ens presenta a un $\mathrm{Mb}$ que vol salvaguardar les «antigues tradicions», les "antigues" maneres de viure, els "antics» costums, però per què?, amb quin benefici?, amb quina perspectiva de futur? Qüestionem aquesta tesi del medecinaire com a director d'un poble cap el seu propi ahir a partir de les paraules d'en Lévi-Strauss:

«Ahora bien, otro género de evolución que se observa en partes del mundo tales como Asia, Africa y América andina, $/ \ldots /$ Se trata de regiones con alta densidad de población y donde, lejos de disminuir, ésta tiende más bien a crecer. La amenaza que suspenden sobre nuestros estudios es pues de otro orden, cualitativo más que cuantitativo: esas grandes poblaciones se transforman a un ritmo rápido y su cultura se apro- 
xima a la del mundo occidental, escapando con ello a nuestra jurisdicción. Esto no es todo, pues esos pueblos toleran cada vez menos el ser cometidos a indagación etnográfica, como si sospecharan que quisiéramos, al estudiar el modo en que sus creencias y costumbres difieren de las nuestras, dar un valor positivo a estas diferencias, frenar su evode las nuestras, (Levi-Strauss, 1980: 54).

Sens dubte són moltes preguntes les que ens fem. Però tornem a les paraules que clouen el llibre de Mallart i que gairebé acabem de citar. Com hem vist, el propòsit de Mba segons Mallart i sense qüestionar el seu encert és impedir el canvi de la societat evuzok d'un estat democràtic -igualitaria a un altre autocràtic - jerarquitzat-. Tanmateix sempre ens sentirem en la necessitat de saber com s'articula exactament la Dansa en una societat artificialment natural o naturalment artificial segons que hem vist. I no és que demanem a Mallart un nou estudi que no pretenia, sinó simplement una que demanem a Mada de la dansa en el seu caldo de cultiu; ¿o és que tot és una bonica narració de Mba inspirada en el seu ambient?

No era vanament que Godelier a 1972 escrivia:

"Una morfología estructural sin análisis de las funciones, sin "fisiología", es incompleta y sólo el desarrollo conjunto de los dos campos de investigación permititá plantear correctamente los problemas de las transformaciones y de la evolución de los sistemas, los problemas de la historia. (Godelier, 1976: 63).

És obvi que aquesta cita va adreçada no concretament a Mallart sinó a l'estructuralisme, però a través d'ella ens introduïm de ple en la mena de manipulació que Mallart fa del document que presenta. Gosaríem a dir que la Dansa als esperits, malgrat el caire de denúncia que en certs moments pren i l'apunt de coneixement global de la societat Evuzok, només inclou un propòsit. Propòsit que és definible amb una expressió i una consideració de diccionari. L'expressió:

"No hay nada humano $-\mathrm{y}$ hasta posiblemente nada orgánico- que sea infinitamente maleable. El número de posibles estructuras en cada caso es limitado. Bajo gran número de variaciones superficiales hay una cantidad limitada de estructuras profundas.» (Ferrater Mora, 1049).

La consideració:

"Los estudios estructuralistas consisten en gran parte en llevar a cabo transformaciones que hacen posible pasar de una estructura a otra me- diante cambios de elementos que no alteran el sistema estructural.n ( $\mathrm{Fe}$ rrater Mora, 1049).

Així, doncs, l'ambigüitat que propugna el full de propaganda i que certerament apunta queda desnonat. De la Dansa als esperits senzillament en resulta una anàlisi estructural. És la recerca en un relat iniciàtic, i la Dansa que li dóna credibilitat, de l'estructura d'un mite. D'allò que en paraules de Godelier:

«Para Marx y para Lévi-Strauss, una estructura no es una realidad directamente observable, sino que es un nivel de la realidad que existe más allá de las relaciones visibles de los hombres entre sí y cuyo funcionamiento constituye la lógica profunda del sistema, el orden subyacente a partir del cual debe explicarse el orden aparente.» (Godelier, 1976: 27).

D'aquí els estudis comparats de diferents tipus de relats, les comparacions estructurals entre les iniciacions de Mba Owona i Sant Pau, o en altres aspectes amb Jesucrist. Les contínues allusions als xamans siberians o amerindis i en general tots els continguts que Mallart ordena en taules d'anàlisi; repeticions estructurals a l'elecció i iniciació, tipus d'antropofàgia, tipus d'àpats, tema de l'engany...

S'esdevé però que aquest propòsit apareix disfressat de furtives escapades (i per això incompletes) a la realitat del poble evuzok, i d'un clar discurs anticolonial que aportant al conjunt una ambigüitat, fascina, tot $\mathrm{i}$ que deixant el lector amb un peu en la societat evuzok i l'altra en el buit. I és que Mallart sap bé a qui s'adreça, i què representa el seu llibre. Ja en parlarem.

Ara sens dubte s'expliquen moltes «dificultats» d'aquest volum; esperem que el nostre discurs hagi contribuit a clarificar-les. Ara s'explica perquè $\mathrm{Ma}$ llart no indica com s'estructura la dansa en el poble que la crea. Hom sap que l'estructuralisme s'oposa a l'historicisme, i com en cas de seguir dogmàticament Lévi-Strauss, aquest s'oposa fins $\mathrm{i}$ tot al funcionalisme. I és que prenent de nou les paraules del diccionari: «En el caso de las estructuras sociales $(\ldots)$ se presupone que hay modelos de vida social y que tienen que explicarse sincrónicamenten. Ês a dir, rebutjant la història $\mathrm{i}$ amb ella les transformacions i canvis socials.

La crítica que nosaltres podríem fer $\mathrm{i}$ en certa mesura hem fet respecte a la manipulació (tornem-hi) del document sobre la Dansa als esperits que Mba lliura a Mallart, la fa Godelier a Lévi-Strauss referint-se al parentiu:

«El análisis estructural no abarca la historia porque desde el principio ha separado el análisis de la forma de las relaciones de parentesco del 
análisis de sus funciones. No es que niegue tales funciones sino que jamás las explora como tales y gracias a ello nunca ha analizado el problema de la articulación real de las relaciones de parentesco y de las restantes estructuras sociales que caracterizan las sociedades concretas, históricamente determinadas, realidades concretas en cuyo seno LéviStrauss se limita a descubrir el "sistema formal" de las relaciones de parentesco parecidas u opuestas. Es obvio que Lévi-Strauss no ignora dichos problemas, pero jamás los ha estudiado sistemáticamente. Son, sin embargo, unos problemas fundamentales cuyas soluciones no solamente permitirán pensar la forma sino también el contenido de las relaciones sociales, sus condiciones de aparición o desaparición, es decir, la Historia humana a través de su propia historia.» (Godelier, 1976: 62-63).

Certament el text és prou iHustratiu i adaptable al nostre cas. I si en voleu un de més neutre cal recollir aquest paràgraf del mateix autor:

«Por consiguiente, ir más allá de una morfología estructural es describir a un tiempo unas formas, unas funciones, un modo de articulación y unas condiciones de transformación de las estructuras sociales en el seno de las sociedades concretas estudiadas por el historiador y el antropólogo.» (Godelier, 1976: 65).

Cal dir quelcom més al respecte? Potser sí. Fins i tot Lévi-Strauss quan analitza la relació entre vius i morts entre els Bororo, fa una somera descripció de la societat i entorn d'aquests indigenes, contextualitzant-los. Una altra cosa és que expliqui l'articulació en aquella societat d'aquella relació (vid. LÉvi-Strauss, 1969: 203-249). Mallart, en canvi, en cas d'oferir-nos-la en ofereix la societat en negatiu. De mostra un botó:

«Es interessant constatar que en aquest primer nivell d'estructuració de la societat dels Esperits, aquesta és concebuda com una societat matriarcal (el poder de governar està a mans d'un esperit femení) i poliàndrica (aquest esperit femení té diversos marits), la qual cosa apareix com una inversió de la realitat mateixa car ni la poliàndria ni el matriarcat no existeixen realment entre els Evuzok،" (Mallart, 1983; 33).

Clarificat aquest punt i abans de concloure el treball, hem de fer esment, per força, de l'evocació del procés de colonització o d'occidentalització de la societat camerunesa en particular, però africana en general. Evidentment, com es pot intuir ràpidament pel que s'ha dit fins ara, Mallart no descriu la situació, únicament en veu reflexes en processos cognitius lligats a l'explicació de la Dansa als Esperits, i a partir d'ells conclou en més d'una ocasió en termes semblants a aquests:
«Com ho demostren aquests exemples, el llenguatge emprat per a representar-se la causalitat d'aquestes malalties és teixit d'imatges tretes de l'època colonial (i neocolonial!) en la qual, podríem dir parafrasejant, I"'ànima" d'aquests pobles (la seva identitat cultural, és cert, però també la seva existència material) va ser completament subjugada, Es important constatar que certes formes d'alienació mental siguin explicades actual. ment mitjançant un llenguatge simbòlic que evoca l'explotació de l'home per l'home. Això ens mostra que la bruixeria evuzok pot ser interpretada com una forma de discurs ideològic a través del qual una societat intenta protestar, conjurar i controlar qualsevol forma d'abús de poder, de dominació o d'explotació, ja sigui d'origen tradicional, ja sigui d'origen colonial.» (Mallart, 1983: 215-216).

La situació real, hom se l'ha d'imaginar en llegir fragments del relat de Mba com ara:

«El meu germà, Ntzama Lucien, és a París. Jo sóc el segon. Els altres dos treballen a Yaundé, l'un és pintor, i l'altre treballa en una fàbrica de gel. El cinquè va al collegi i el més petit, el que vingué a veure'm, viu aquí, al poblat.» (Mallart, 1983: 124).

Però com està la societat camerunesa no ho explicita en cap moment. El problema és interessant $\mathrm{i}$ suggestiu, $\mathrm{i}$ a més, és el que pot atraure el lector d'una manera més decisiva, fer-li prendre partit. Ês clar que tampoc descriu una sensació com la que va experimentar Godelier en arribar junt als baruia a l'interior de Nova Guinea a mitjan de la dècada dels seixanta:

«Es decir, en unos valles aislados de las montañas de Nueva Guinea la historia se me ofrecía de manera privilegiada en un salto gigantesco que abolía bajo mis ojos la distancia que separaba en el espacio y en el tiempo dos formas extremas de su desarrollo, una sociedad primitiva que apenas acababa de cerrar a sus espaldas la puerta del neolítico para encontrarse frente a frente con unos extranjeros que se arrogaban el "derecho", en nombre de la "superioridad" de su propio sistema social y de sus valores, de "pacificarla" militarmente, de "civilizarla" y de convertirla en objeto de estudio antropológico; en pocas palabras, de someterla a partir de aquel momento al orden de un mundo europeo que ya no era el de $\mathrm{He}$ rodoto o de Cortés, sino el de la exploración de la luna y de las guerras imperialistas.» (Godelier, 1976: 14-15.)

No és igual en el sentit que els pobles camerunesos «coneixen» a desgrat seu, suposem des de fa bastant més anys que els australs l'home blanc, i no ho són tampoc en el sentit que els camerunesos, tot i que no se'ns diu res 
de la seva economia, sembla que no acaben de superar l'etapa paleolítica. Sí que ho és quant al dret, la superioritat, l'ànim de militarització o de pacificació que l'home blanc vol imposar. Són molts els elements que hom pot extraure del text de Mallart que hi fan referència. Més d'un d'ells ja els hem sentit i no cal tornar-hi.

De fet, ningú pot oblidar que:

* La antropología nació de un devenir histórico en el curso del cual la mayor parte de la humanidad fue sometida por otra, $y$ en el que millones de inocentes víctimas vieron sus recursos saqueados, sus creencias y sus instituciones destruidas antes de ser, ellas mismas, salvajemente exterminadas, reducidas a la servidumbre o contaminadas por enfermedades contra las que su organismo no proporcionaba defensas. La antropología es hija de una era de violencia, y si se ha vuelto capaz de adquirir de los fenómenos humanos una visión más objetiva que en otro tiempo, debe esta ventaja epistemológica a un estado de hecho en el que una parte de la humanidad se arrogó el derecho de tratar a la otra como un objeto.» (Lévi-Strauss, 9180; 56).

El fragment és cru però cert. Sort del canvi d'inflexió que propugna l'antropòleg franco-belga. De fet però, el sistema colonial o el neocolonial que encara és pitjor, ja que implica una subtil explotació econòmica i un desig d'adhesió a les noves formes occidentals per part dels indígenes, per força desemboca en un trasbals. Potser és que l'antropologia haurà de passar a ser en alguna de les seves vessants, $\mathrm{i}$ quan els pobles anomenats primitius hagin desaparegut del tot, una ciència aplicada per les patologies dels països sub. desenvolupats. Lévi-Strauss (vid. 1980: 53) presenta aquesta possibilitat.

Si ens permetem l'expressió, aquest procés ha derivat en una tragèdia fins a cert punt còmica o risible, però angoixosament trista. Podríem dir que $\mathrm{e}$ blanc acultura $\mathrm{i}$ potser ara ja, el blanc també cura. De fet, mai no coneixerem del tot els trasbalsos que han hagut de patir pobles com el de $\mathrm{Mb}$ Owona. Experiències que fan pensar i repensar, què som, què és la humanitat o si és que fins ara només ho erem uns quants.

¿Ês doncs que Mba Owona representa l'heroisme de la resistència anticolonial? Mallart ho afirma més o menys clarament. Del que no hi ha dubte és que Mba és fill d'unes circumstàncies precises. ¿Què és Yaundé la capital del Camerun?, què són les aldees evuzok? L'àmbit s'escapa al llibre de Mallart. Aquest només ens permet la reflexió, l'especulació i el dubte; en cara que ens assegura la crisi de la societat camerunesa, ¿quina és aquesta societat? ¿la pigmea, l'evuzok (bantú), la de la ciutat? Com hem vist, no és el propòsit de Mallart contestar-ho. La seva pretensió és simplement la d'una anàlisi estructural d'un sistema - la dansa als esperits - seguint una tradició que ja s'estronca. Ho encerta.

Evidentment no podem estimar per què l'autor ha redactat el llibre de la manera com ho ha fet. Tanmateix podem donar una explicació: Mallart sap ben bé quin paper pot jugar la seva obra en una societat en crisi com la catalana. És més, la seva obra és la primera del gènere. Obre camí $\mathrm{i}$ cal que sigui atractiva. Tot i les mancances ho és. Ess més, és sobretot que ho és, d'atractiva.

\section{BIBLIOGRAFIA}

Ferriter Mora, J.

1981 (3) Diccionario de Filosofia, II. Madrid, Alianza Editorial, pp. 1046 -

GoDELIER, M.

1976 Funcionalismo, estructuralismo y marxismo. Barcelona, Cuadernos Levi-Strauss, C.

1969 Tristos Tròpics. Barcelona, Anagrama.

LeVi-Strauss, C.

1980 "La obra del American Bureau of Ethnology y sus lecciones». A: MaLlart, LI. Antropologia Estructural. Madrid, Siglo XXI, pp. 51-61.

La Dansa als esperits. Itinerari iniciàtic d'un medecinaire africà. Barcelona, Punt de vista, 2. La Llar del Llibre. 